DOI: $10.1515 / \mathrm{rrlm}-2017-0003$

\title{
Evaluation of C677T and A1298C polymorphism of the methylenetetrahydrofolate reductase gene as a maternal risk factor for trisomy 21 (a monocentric study)
}

\author{
Polimorfismul C677T si A1298C al genei MTHFR ca factor \\ de risc matern pentru trisomia 21 (studiu monocentric)
}

\author{
Simona Bucerzan ${ }^{1}$, Radu Anghel Popp 2 , Raluca Maria Vlad ${ }^{3}$, \\ Cecilia Lazea,*, Radu Nicolaescu ${ }^{5}$, Paula Grigorescu-Sido ${ }^{1}$ \\ 'University of Medicine and Pharmacy ,,Iuliu Hațieganu”, Centre of Genetic Diseases, Emergency \\ Pediatric Hospital, Cluj-Napoca, Romania, \\ ${ }^{2}$ University of Medicine and Pharmacy ,Iuliu Hațieganu”, Medical Genetics Department, Emergency \\ Pediatric Hospital, Cluj-Napoca, Romania, \\ ${ }^{3}$ Carol Davila University of Medicine and Pharmacy, Department of Pediatrics, Grigore Alexandrescu \\ Emergency Pediatric Hospital, Bucharest, Romania, \\ ${ }^{4}$ University of Medicine and Pharmacy ,Iuliu Hațieganu”, Medical Genetics Department, Emergency \\ Pediatric Hospital, Cluj-Napoca, Romania, \\ ${ }^{5}$ Radiology and Medical Imaging Laboratory, Fundeni Clinical Institute, Bucharest, Romania
}

\begin{abstract}
Aim: To assess the risk for trisomy 21 in children, depending on the polymorphisms C677T and A1298C of the methylenetetrahydrofolate reductase (MTHFR) gene in mothers.

Methods: For 93 mothers who have children with trisomy 21 and 202 mothers of healthy children (control group), genotyping of MTHFR polymorphisms C677T and A1298C was performed.

Results: For each polymorphism, three genotypes were identified (normal homozygous, heterozygous and mutant homozygous). For the polymorphism C677T, the frequencies of the three genotypes (CC, CT and TT) were 50.5\%, 40.8\% and $8.6 \%$ in mothers of children with trisomy 21 , versus $42.6 \%, 46 \%$ and $11.4 \%$ in mothers of healthy children, with no statistically significant differences. The frequency of the polymorphism A1298C was not statistically significant between the two groups for the genotype (AA) $(48.4 \%$ vs $56.4 \%)$ or the genotype (AC) (39.8\% vs 38.6\%), but the genotype TT was more frequent in mothers of children with trisomy $21(11.8 \% \mathrm{vs} 4.9 \% ; p=0.033 ; \mathrm{OR}=2.57)$.

Conclusion: Women with genotype CC for the polymorphism A1298C of the MTHFR gene have a 2.57 times higher risk of offspring with trisomy 21.
\end{abstract}

Keywords: MTHFR gene, polymorphism, Down syndrome.

* Corresponding author: Cecilia Lazea, University of Medicine and Pharmacy „Iuliu Haţieganu”, 68 Motilor Street, Cluj-Napoca, Romania, e-mail: cicilazearo@yahoo.com 


\section{Rezumat}

Obiective. Obiectivele studiului au fost evaluarea riscului de a avea copii cu trisomie 21 la femeile care prezintă polimorfismele C677T și A1298C ale genei metilentetrahidrofolatreductaza (MTHFR).

Material și metode. Studiul a inclus 93 de mame care aveau copii cu trisomie 21 și 202 mame care aveau copii sănătoși (lotul martor), la care s-a detectat prezența polimorfismelor C677T și A1298C ale genei MTHFR.

Rezultate. Pentru fiecare polimorfism au fost identificate următoarele genotipuri: homozigot, heterozigot și homozigot mutant. In cazul polimorfismului C677T, frecvența celor 3 genotipuri (CC, CT și TT) a fost de 50,5\%, 40,8\% și respectiv 8,6\% in cazul femeilor care aveau copii cu trisomie 21 față de 42,6\%, 46\% și respectiv 11,4\% în cazul femeilor care aveau copii sănătoși, fără a fi înregistrate diferențe statistic semnificative. Frecvența polimorfismului A1298C nu a înregistrat diferențe statistic semnificative între cele două grupuri, fiind 48,4\% vs 56,4\% pentru genotipul AA și respectiv 39,8\% vs 38,6\% pentru genotipul AT, dar genotipul TT a fost mai frecvent întâlnit în cazul femeilor care aveau copii cu trisomie 21 (11,8\% vs 4,9\%; $p=0,033 ;$ OR $=2,57)$.

Concluzii. Femeile care prezintă genotipul CC pentru polimorfismul A1298C al genei MTHFR, au un risc de 2,57 ori mai mare de a avea copii cu trisomie 21.

Cuvinte cheie: gena MTHFR, polimorfism, sindrom Down.

Received: 12 $2^{\text {th }}$ October 2016; Accepted: 14 ${ }^{\text {th }}$ December 2016; Published: $14^{\text {th }}$ January 2017

\section{Introduction}

Folates are basic resources for biosynthesis. Their metabolism requires reduction and methylation of folate to 5-methyl tetrahydrofolate. The latter is then used for the synthesis of DNA and RNA precursors or for conversion of homocysteine to methionine, the substrate for a primary DNA methylation agent, namely S-adenosylmethionine (1). Abnormalities in the metabolism of folate and/or differences in the genes (polymorphisms) encoding enzymes involved have been described as potential risk factors for chromosomal diseases, especially trisomy 21 (2, 3 ). Folate deficiency and deficiency of donors of methyl groups at the cellular level are both associated with abnormal methylation in DNA, chromosomal instability, rupture of DNA chains, aberrant chromosomal recombination, abnormal chromosome segregation, and meiotic nondisjunction of chromosomes and aneuploidies $(1,4,5)$. A hypothesis has been advanced that genitors of patients with trisomy 21 , especially mothers, have polymorphisms in genes encoding methylenetetrahydrofolate reductase (MTHFR) - MTHFR gene (MIM *607093), methionine synthase reductase (MTRR) - MTRR gene (MIM
*602568) and/or methionine synthase (MTR) MTR gene (MIM *156570), and consequently possess altered metabolism of folate and homocysteine (2-4, 6-18). Another hypothesis states the involvement of other genes, such as methylenetetrahydrofolate dehydrogenase (5, 19). James et al. (1999) reported that mothers of children with trisomy 21 , unlike mothers of healthy children, have abnormalities in the folate metabolism, abnormalities which may be partly explained by a variation in the MTHFR gene (MIM*607093) sequence (2). Hobbs et al. (2000) noted that a combination of two polymorphisms in two genes (MTHFR gene (MIM*607093) and MTRR gene (MIM*602568)) was associated with a higher risk of trisomy 21 in children than were any of the individual polymorphisms (3). Rai et al. (2006) reported in Eastern India that the presence of two polymorphisms of the MTHFR gene (MIM *607093) (C677T and A1298C) increased the risk of trisomy 21 to a greater extent than the presence of a single polymorphism (9). Other studies failed to demonstrate correlations between MTHFR gene $(M I M * 607093)$ polymorphisms and the risk of trisomy 21 in children (20-24). 
In recent years, the maternal polymorphisms of this gene have raised increasing interest, generating meta-analyses, but the results remain contradictory and the literature has yet to find a consensus. Rai et al. (2014) demonstrated in a meta-analysis of 34 studies (published between 1999 and 2014), that maternal polymorphism C677T of the MTHFR gene (MIM *607093) represented a risk factor for trisomy 21 in children (25), whereas the meta-analysis (studies from 2000 to 2013) of Yang et al. (2013) did not find any correlation (26).

To date, there are no Romanian data about maternal polymorphismofthe MTHFR gene (MIM *607093) and the risk of aneuploidy in children. One single Romanian publication (Neagos et al., 2010) evaluated the relationship between polymorphism of the methylenetetrahydrofolate dehydrogenase - MTHFD gene (MIM*172460) and the risk of trisomy 21 and concluded that there was no significant correlation (5). The aim of this study is to assess the risk of trisomy 21 in children in relation to the different genotypes or combinations of genotypes for the polymorphisms C677T and A1298C of the MTHFR gene (MIM *607093) in Romanian mothers.

\section{Patients and methods}

A prospective study was carried out in the Medical Genetics Department of the Children's Emergency Hospital, Cluj-Napoca. The group consisted of 93 mothers of children with trisomy 21 and 202 mothers of children with normal karyotype (control group). A blood sample was collected from each subject and genotype was analysed for polymorphisms, specifically MTHFR gene (MIM *607093) C677T and A1298C.

The study was approved by the Ethics Committee of the hospital and written informed consent was obtained from participants prior to enrolment.
Genomic DNA was extracted from each $300 \mu \mathrm{L}$ blood sample collected with EDTA using a commercial kit (Wizard Genomic DNA Purification Kit, Promega, MA, USA). DNA quality and quantity were analysed using the photometry method (Biophotometer Plus, Eppendorf, Germany).

MTHFR genotype analysis was performed by polymerase chain reaction-restriction fragment length polymorphism (PCR-RFLP), using a protocol described by Zhou-Cun et al. (2007) for the variant C677T (27), and protocols described by Friedman et al. (1999) and van der Put et al. (1998) for the variant A1298C, with some modifications $(28,29)$. Amplification of each sample was performed using $12.5 \mu \mathrm{L}$ PCR Mix (recombinant Taq polymerase $0.05 \mathrm{IU} / \mathrm{mL}$, $\mathrm{MgCl}_{2} 4 \mathrm{mM}$, dATP, dGTP, dCTP, dTTP at a concentration of $0.4 \mathrm{mM}$ each), $1 \mu \mathrm{L}$ solution of bovine serum albumin (BSA) $2 \mathrm{mg} / \mathrm{mL}, 1 \mu \mathrm{L}$ solution for each primer $(1.5 \mathrm{pmol} / \mu \mathrm{L}), 2 \mu \mathrm{L}$ DNA and nuclease-free water to a final volume of $25 \mu \mathrm{L}$. The amplicons obtained from the PCR were digested with the appropriate restriction enzyme (FastDigest HinfI for the C677T variant and FastDigest MboII for the variant A1298C) and identification of digestion products was performed by horizontal electrophoresis in $2.5 \%$ agarose gel.

Data were statistically analysed using Microsoft Excel and SPSS v 20.

Each gene variant was tested for HardyWeinberg equilibrium, both in the mothers of Down syndrome group and in the control group; the test was validated for $p>0.05$. The frequencies of each genotype were calculated individually and the values were compared between groups using a chi-square test, considering values statistically significant for $p<0.05$. The riskodds ratio (OR) was assessed when comparing the two groups. The interactions between the two genotypes (MTHFR C677T and MTHFR 
A1298C) were also evaluated, calculating their frequencies in each group and comparing the two groups.

The study was performed in accordance with the code of Ethics of the World Medical Association (Declaration of Helsinki) for experiments in humans.

\section{Results}

\section{Genotype analysis and the risk of trisomy 21} The distribution of the MTHFR C677T genotype in the group of mothers of Down syndrome $(\mathrm{p}=$ $0.9353)$ and in the control group $(p=0.7761)$ respected the Hardy-Weinberg equilibrium (Table 1). The heterozygous genotype CT and homozygous genotype TT were found in $40.8 \%$ and $8.6 \%$ of mothers of trisomy 21 children and in $46 \%$ and $11.4 \%$, of the control group, respectively, with no significant differences between the two groups. The combination of the two genotypes (CT/TT) was not more common among mothers of trisomy 21 children with $(\mathrm{p}$ $>0.05)$.

The distribution of the MTHFR A1298C genotype in the group of mothers of Down syndrome $(\mathrm{p}=0.9736)$ and in the control group $(p=0.9736)$ respected the Hardy-Weinberg equilibrium (Table 2). The heterozygous genotype $\mathrm{AC}$ and the combination of the two genotypes $(\mathrm{AC} / \mathrm{CC})$ were more common in the mothers of Down syndrome than in the control group (39.8\% vs $38.6 \%$ and $51.6 \%$ vs. $43.5 \%)$, but the differences were not statistically significant $(p>0.05)$. The frequency of the homozygous CC genotype of the A1298C MTHFR polymorphism, however, was significantly higher in the group of mothers of Down syndrome children, OR 2.57, CI $1.053-6.301(\mathrm{p}=0.033)$.

\section{Analysis of interactions between genotypes and the risk of trisomy}

We evaluated the combinations of genotypes for the variant alleles MTHFR C677T and A1298C (Table 3). None of the combinations proved to have any significant association with the risk for trisomy 21 in children.

\section{Discussion}

In the last decade, interest in evaluating polymorphisms of the maternal genes involved in folate metabolism in relation to the risk of trisomy 21 has increased in medical literature worldwide. Various enzymes involved in metabolic pathways of the folates were studied and different groups obtained contradictory results. The explanation could be rooted in variations of genetic structure in different populations and ethnic groups, in which different epigenetic and environmental factors are involved.

Table 1. Frequency of the genotype MTHFR C677T in two groups of mothers: those of children with trisomy 21 and those of children with a normal karyotype (control group)

\begin{tabular}{llllll}
\hline $\begin{array}{l}\text { Genotype } \\
\text { MTHFR } \\
\text { C677T }\end{array}$ & $\begin{array}{l}\text { Mothers of } \\
\text { children with } \\
\text { trisomy 21 } \\
\text { no. }(\%)\end{array}$ & $\begin{array}{l}\text { Control } \\
\text { group } \\
\text { no. }(\%)\end{array}$ & OR & 95\% CI & p \\
\hline Homozygous CC & $47(50.5)$ & $86(42.6)$ & 1.378 & {$[0.842-2.256]$} & 0.202 \\
\hline Heterozygous CT & $38(40.8)$ & $93(46)$ & 0.810 & {$[0.492-1.332]$} & 0.405 \\
\hline Homozygous TT & $8(8.6)$ & $23(11.4)$ & 0.732 & {$[0.315-1.705]$} & 0.469 \\
\hline CT / TT & $46(49.5)$ & $116(57.4)$ & 0.717 & {$[0.438-1.175]$} & 0.186 \\
\hline
\end{tabular}


Table 2. Frequency of the genotype MTHFR A1298C in two groups of mothers: those of children with trisomy 21 and those of children with a normal karyotype (control group)

\begin{tabular}{llllll}
\hline $\begin{array}{l}\text { Genotype } \\
\text { MTHFR } \\
\text { A1298A }\end{array}$ & $\begin{array}{l}\text { Mothers of } \\
\text { children with } \\
\text { trisomy 21 } \\
\text { no. }(\%)\end{array}$ & $\begin{array}{l}\text { Control } \\
\text { group } \\
\text { no. }(\%)\end{array}$ & OR & 95\% CI & p \\
\hline Homozygous AA & $45(48.4)$ & $114(56.4)$ & 0.724 & {$[0.442-1.184]$} & 0.198 \\
\hline Heterozygous AC & $37(39.8)$ & $78(38.6)$ & 1.050 & {$[0.635-1.736]$} & 0.848 \\
\hline Homozygous CC & $11(11.8)$ & $10(4.9)$ & 2.576 & {$[1.053-6.301]$} & 0.033 \\
\hline AC / CC & $48(51.6)$ & $88(43.5)$ & 1.382 & {$[0.844-2.262]$} & 0.198 \\
\hline
\end{tabular}

Table 3. Interactions between the genotypes MTHFR C677G and A1298C in two groups of mothers: those of children with trisomy 21 and those of children with a normal karyotype (control group)

\begin{tabular}{|c|c|c|c|c|c|c|}
\hline $\begin{array}{l}\text { MTHFR } \\
\text { C677T }\end{array}$ & $\begin{array}{l}\text { MTHFR } \\
\text { A1298A }\end{array}$ & $\begin{array}{l}\text { Mothers } \\
\text { of children } \\
\text { with } \\
\text { trisomy } 21 \\
\text { no. }(\%) \\
\end{array}$ & $\begin{array}{l}\text { Control } \\
\text { group } \\
\text { no. }(\%)\end{array}$ & OR & $95 \% \mathrm{CI}$ & $\mathbf{p}$ \\
\hline Heterozygous CT & Heterozygous AC & $16(17.2)$ & $35(17.3)$ & 0.991 & {$[0.517-1.900]$} & 0.979 \\
\hline Heterozygous CT & Homozygous CC & $1(1)$ & $6(2.9)$ & 0.355 & {$[0.042-2.992]$} & 0.320 \\
\hline Homozygous TT & Heterozygous AC & $0(0)$ & $3(1.4)$ & & & 0.237 \\
\hline $\mathrm{CT} / \mathrm{TT}$ & $\mathrm{AC} / \mathrm{CC}$ & $17(18.3)$ & $41(20.3)$ & 0.878 & {$[0.469-1.646]$} & 0.685 \\
\hline
\end{tabular}

In the present study, we assessed the frequency of different genotypes of polymorphisms C677T and A1298C of the MTHFR gene (MIM *607093) in a Romanian population.

Since 2000, numerous studies have compared the frequencies of the genotypes for the two polymorphisms of the MTHFR gene (MIM *607093) between mothers of children with trisomy 21 and mothers of healthy children. A comparison of the results of those previous studies and of the present study are presented in Table 4.

Our results did not show increased frequencies of the heterozygous CT and homozygous TT genotype C677T in the group of mothers of trisomy 21 compared to controls.
Similar results were found by Stuppia et al. (2002) in an Italian population (22) and by Kohli et al. (2004) in a population in Eastern India (20). There were no statistically significant differences between the two groups. Our study did not show any correlation between maternal C677T polymorphism of the MTHFR gene (MIM *607093) and the risk of trisomy 21 in children, in agreement with other studies carried out in Denmark (21), Turkey (23), and Croatia (24).

Other publications, however, have revealed an increased risk of trisomy 21 in offspring of mothers having a heterozygous genotype CT or homozygous genotype TT. Hobbs et al. (2000) observed that the heterozygous genotype C677T of the MTHFR gene (MIM *607093) 
Table 4. Frequency of genotypes of MTHFR C677T in two groups of mothers: those of children with trisomy 21 and those of children with a normal karyotype (control group). The results of previous studies are compared with the present study.

\begin{tabular}{|c|c|c|c|c|c|c|c|c|c|}
\hline \multirow{2}{*}{ Year } & \multirow[b]{2}{*}{$\begin{array}{c}\text { Study } \\
\text { (reference) }\end{array}$} & \multicolumn{2}{|c|}{$\begin{array}{c}\text { Homozygous } \\
\text { CC }\end{array}$} & \multicolumn{2}{|c|}{$\begin{array}{c}\text { Heterozygous } \\
\text { CT } \\
\end{array}$} & \multicolumn{2}{|c|}{ Homozygous TT } & \multicolumn{2}{|c|}{$\mathrm{CT} / \mathrm{TT}$} \\
\hline & & $\begin{array}{c}\text { Mothers } \\
\text { of } \\
\text { trisomy } \\
21(\%)\end{array}$ & $\begin{array}{l}\text { Control } \\
\text { group } \\
(\%)\end{array}$ & $\begin{array}{c}\text { Mothers } \\
\text { of } \\
\text { trisomy } \\
21(\%)\end{array}$ & $\begin{array}{c}\text { Control } \\
\text { group } \\
(\%)\end{array}$ & $\begin{array}{c}\text { Mothers } \\
\text { of } \\
\text { trisomy } \\
21(\%)\end{array}$ & $\begin{array}{l}\text { Control } \\
\text { group } \\
(\%)\end{array}$ & $\begin{array}{c}\text { Mothers } \\
\text { of } \\
\text { trisomy } \\
21(\%)\end{array}$ & $\begin{array}{c}\text { Control } \\
\text { group } \\
(\%)\end{array}$ \\
\hline 2000 & Hobbs et al. (3) & 31 & 48 & 54 & 42 & 14 & 10 & 68 & 52 \\
\hline 2002 & Stuppia et al. (22) & 31 & 24.1 & 50.7 & 55.4 & 18.3 & 20.5 & 69 & 75.9 \\
\hline 2006 & Rai et al. (9) & 65.1 & 75.1 & 26.8 & 23.6 & 8 & 1.2 & 34.8 & 24.8 \\
\hline 2008 & Biselli et al. (12) & 40.3 & 51.5 & 48.6 & 39.7 & 11.1 & 8.8 & 59.7 & 48.5 \\
\hline 2008 & Kohli et al. (20) & 71.8 & 65.1 & 28.2 & 29.4 & 0 & 5.5 & 28.1 & 34.9 \\
\hline 2008 & Meguid et al. (13) & 47.6 & 68.8 & 40.5 & 25 & 11.9 & 6.2 & 52.4 & 31.2 \\
\hline 2008 & Wang et al. (11) & 21.8 & 51.4 & 50 & 41.4 & 28.2 & 7.2 & 78.2 & 48.6 \\
\hline 2012 & Zampieri et al. (17) & 38.1 & 50.8 & 52.4 & 39.5 & 9.5 & 9.7 & 61.9 & 49.2 \\
\hline 2012 & Mohanty et al. (30) & 84.6 & 94.2 & 15.4 & 5.9 & 0 & 0 & 15.4 & 5.9 \\
\hline 2016 & Present study & 50.5 & 42.6 & 40.8 & 46 & 8.6 & 11.4 & 49.5 & 57.4 \\
\hline
\end{tabular}

is more frequent in mothers of trisomy 21 children $(\mathrm{OR}=1.91)(3)$. Al-Gazali et al. $(2001)$ demonstrated in an Arab population that altered metabolism of folate status in the context of a maternal homozygous 677TT genotype of the MTHFR gene (MIM *607093) promoted chromosomal instability and the appearance of meiotic non-disjunction, leading to trisomy 21 in offspring (6). Similar results were also found in a Chinese population $(\mathrm{OR}=3.78)(12)$, by Liao et al. (2010) $(\mathrm{OR}=3.51)(15)$ and in an Eastern Indian population by Rai et al. (2006) with a relative risk of $7(\mathrm{OR}=7.67 ; \mathrm{p}=0.003)$ (9). The homozygous 677TT and heterozygous 677CT genotypes together were significantly more common among mothers of patients with trisomy 21 in an Egyptian population studied by Meguid et al. (2008) (13).

For polymorphism A1298C of MTHFR, the present study reported similar results to those published by Rai et al. in India (9), Biselli et al. (12), and Zampieri et al. in Brazil (17), which showed that the combination of the two genotypes (heterozygous AC/homozygous CC) was more frequent in mothers of trisomy 21 children than in controls. These differences were not statistically significant in the current study, however.

The homozygous genotype $\mathrm{CC}$ for the A1298C polymorphism of MTHFR gene (MIM *607093) was significantly more common among mothers of trisomy 21 than in the control group in our study ( $11.8 \%$ and $4.9 \%$, respectively), which is similar to the findings of Meguid et al. (2008) in an Egyptian population (33.3\% vs. $2.1 \%)$ (13) and Rai et al. (24.1\% vs. $7.1 \%)$ in an Indian population (9). The results of Meguid et al. showed that the genotype $1298 \mathrm{CC}$ was correlated with a higher risk of women having children with trisomy $21(\mathrm{OR}=2.57 ; \mathrm{p}=0.033)$, 
whereas Rai et al. indicated a relative risk of 4 $(\mathrm{OR}=4.4 ; \mathrm{p}=0.008)(9)$. In contrast, there were no correlations between a maternal MTHFR A1298C polymorphism and risk of trisomy 21 in offspring in studies from India (14), Denmark (21), Turkey (23), and Croatia (24).

In this study, we performed an analysis of combined genotypes for two polymorphisms of the MTHFR gene (MIM *607093), C677T and A1298C, in relation to risk of trisomy 21 because there are previous studies that have demonstrated a significant risk of trisomy 21 in offspring in the presence of both maternal polymorphisms. For example, Cyril et al. (2009) studied a South Indian population and reported that there was an increased risk of having a child with Down syndrome in cases of maternal polymorphism C677T of MTHFR gene (MIM*607093), and not in cases of maternal polymorphism A1298C of MTHFR gene (MIM*607093) separately, but the study reported an additive risk for mothers with both polymorphisms (14). Biselli et al. reported that each polymorphism of MTHFR gene (MIM *607093) did not involve a significant risk when taken separately, but the presence of $\geq 3$ variant alleles in the maternal genome (MTHFR A1298C, MTHFR C677T, MTR A2756G, RFC1 G80A) were combined factors for the risk of trisomy 21 (12).

These contradictory reports come from studies on different populations (in terms of ethnicity or geographical area), as well as studies on similar populations. Clarifications have been sought by expanding research into polymorphisms in several genes involved in folate metabolism, resulting in publications that have evaluated various combinations. Hobbs et al. reported that the presence of the polymorphism C677T of the MTHFR gene (MIM *607093), together with the homozygous status for the polymorphism A66G of the MTHFR gene $(M I M * 607093)$ is associated with a higher risk than for any of the polymorphisms separately $(\mathrm{OR}=4.08)$ (3), findings also supported by Wang et al. (2008) $(\mathrm{OR}=6)(11)$. Coppede et al. reported that a combination of genotypes for polymorphisms of MTHFR C677T and RFC1 G80A is associated with a border-line risk for trisomy 21 (8).

To date, the concern for this issue was more intense in Chinese $(11,15,18,26)$ and Indian populations $(9,14,20,25)$. There have also been studies in Brazil $(7,12,17)$ and a few studies in Arab populations, such as in the United Arab Emirates (6), Egypt (13) or Jordan (16). Very few studies have been conducted in Caucasian populations and Europe; only in Italy $(8,10$, $22)$, Turkey $(20,24)$, and Croatia (24). To date, the Romanian situation has been reported in a single study investigating the polymorphisms of MTHFD gene (MIM *172460) (5). The present study is therefore the first study to assess polymorphisms of the MTHFR gene (MIM *607093) in Romanian mothers in relation to the risk of trisomy 21 in their children.

Strengths and limitations of the study: To the best of our knowledge, this is the first Romanian study addressing the MTHFR gene polymorphisms and the risk of trisomy 21 in the offspring and also one of the few studies on European Caucasian population. The research was conducted in a single center and included a small cohort of women.

\section{Conclusion}

In a Romanian population, the homozygous genotype CC of the A1298C polymorphism of the MTHFR gene (MIM*607093) is statistically significantly more frequent in mothers of trisomy 21 children than in mothers of children with normal karyotypes. This polymorphism could therefore represent a potential risk factor for trisomy 21 . 


\section{Abbreviations}

$\begin{aligned} \text { MTR }= & \text { Methionine synthase } \\ \text { MTRR = } & \text { Methionine synthase reductase } \\ \text { MTHFD = } & \text { Methylenetetrahydrofolate } \\ & \text { dehydrogenase } \\ \text { MTHFR = } & \text { Methylenetetrahydrofolate } \\ & \text { reductase }\end{aligned}$

\section{References}

1. Coppede F, Grossi E, Migheli F, Migliore L. Polymorphism in folate-metabolizing genes, chromosomal damage, and risk of Down syndrome in Italian women: identification of key factors using artificial neural networks. BMC Med Genomics. 2010, 2010 Sep 24;3:42. DOI: 10.1186/1755-8794-3-42.

2. James SJ, Pogribna M, Pogribny IP, Melnyk S, Hine RJ, Gibson JB, et al. Abnormal folate metabolism and mutation in the methylenetetrahydrofolate reductase gene may be maternal risk factors for Down syndrome. Am J Clin Nutr. 1999 Oct;70(4):495-501.

3. Hobbs CA, Sherman SL, Yi P, Hopkins SE, Torfs CP, Hine RJ, et al. Polymorphisms in genes involved in folate metabolism as maternal risk factors for Down syndrome. Am J Hum Genet. 2000 Sep;67(3):623-30.

4. Cuckle HS. Primary prevention of Down's syndrome. Int J Med Sci. 2005;2(3):93-9.

5. Neagos D, Cretu R, Tutulan-Cunita A, Stoian V, Bohiltea LC. Methylenetetrahydrofolate dehydrogenase (MTHFD) enzyme polymorphism as a maternal risk factor for trisomy 21: a clinical study. J Med Life. 2010 Oct-Dec;3(4):454-7.

6. Al-Gazali LI, Padmanabhan R, Melnyk S, Yi P, Pogribny IP, Pogribna M, et al. Abnormal folate metabolism and genetic polymorphism of the folate pathway in a child with Down syndrome and neural tube defect. Am J Med Genet. 2001 Oct 1;103(2):128-32.

7. da Silva LR, Vergani N, Galdieri L, Ribeiro Porto MP, Longhitano SB, Brunoni D, et al. Relationship between polymorphisms in genes involved in homocysteine metabolism and maternal risk for Down syndrome in Brazil. Am J Med Genet. 2005 Jun 15;135(3):263-7.
8. Coppede F, Marini G, Bargagna S, Stuppia L, Minichilli F, Fontana I, et al. Folate gene polymorphisms and the risk of Down syndrome pregnancies in young Italian women. Am J Med Genet. 2006 May 15;140(10):1083-91.

9. Rai AK, Singh S, Mehta S, Kumar A, Pandey LK, Raman R. MTHFR C677T and A1298C polymorphisms are risk factors for Down's syndrome in Indian mothers. J Hum Genet. 2006;51(4):278-83.

10. Scala I, Granese B, Sellitto M, Salome S, Sammartino A, Pepe A, et al. Analysis of seven maternal polymorphisms of genes involved in homocysteine/folate metabolism and risk of Down syndrome offspring. Genet Med. 2006 Jul;8(7):409-16.

11. Wang SS, Qiao F, Feng L, Lv J. Polymorphism in genes involved in folate metabolism as maternal risk factors for Down syndrome in China. J Zhejiang Univ Sci. 2008 Feb;9(2):93-9. DOI: 10.1631/jzus.B0710599.

12. Biselli JM, Goloni-Bertollo EM, Zampieri BL, Haddad R, Eberlin MN, Pavarino-Bertelli EC. Genetic polymorphisms involved in folate metabolism and elevated plasma concentrations of homocysteine: maternal risk factors for Down syndrome in Brazil. Genet Mol Res. 2008 Jan 22;7(1):33-42.

13. Meguid NA, Dardir AA, Khass M, Hossieny LE, Ezzat A, El Awady MK. MTHFR genetic polymorphism as a risk factor in Egyptian mothers with Down syndrome children. Dis Markers. 2008;24(1):19-26.

14. Cyril C, Rai P, Chandra N, Gopinath PM, Satyamoorthy K. MTHFR Gene variants C677T, A1298C and association with Down syndrome: A Case-control study from South India. Indian J Hum Genet. 2009 May;15(2):604. DOI: $10.4103 / 0971-6866.55217$.

15. Liao YP, Bao MS, Liu CQ, Liu H, Zhang D. Folate gene polymorphism and the risk of Down syndrome pregnancies in young Chinese women. Yi Chuan. 2010 May;32(5):461-6.

16. Sadiq MF, Al-Refai EA, Al-Nasser A, Khassawneh M, Al-Batayneh Q. Methylenetetrahydrofolate reductase polymorphisms C677T and A1298C as maternal risk factors for Down syndrome in Jordan. Genet Test Mol Biomarkers. 2011 Jan-Feb;15(1-2):51-7. DOI: 10.1089/ gtmb.2010.0057.

17. Zampieri BL, Biselli JM, Goloni-Bertollo EM, Vannucchi H, Carvalho VM, Cordeiro JA, et al. Maternal risk for Down syndrome is modulated by genes involved in folate metabolism. Dis Markers. 2012;32(2):73-81. DOI: 10.3233/DMA-2011-0869. 
18. Wu X, Wang X, Chan Y, Jia S, Luo Y, Tang W. Folate metabolism gene polymorphisms MTHFR C677T and A1298C and risk for Down syndrome offspring: a meta-analysis. Eur J Obstet Gynecol Reprod Biol. 2013 Apr;167(2):154-9. DOI: 10.1016/j.ejogrb.2012.11.022.

19. Izci Ay O, Ay ME, Erdal ME, Cayan F, Tekin S, Soylemez F, et al. Folate metabolism gene polymorphisms and risk for down syndrome offspring in Turkish women. Genet Test Mol Biomarkers. 2015 Apr;19(4):191-7. DOI: 10.1089/gtmb.2014.0262.

20. Kohli U, Arora S, Kabra M, Ramakrishnan L, Gulati S, Pandey RM. Prevalence of MTHFR C677T polymorphism in north Indian mothers having babies with Trisomy 21 Down syndrome. Downs Syndr Res Pract. 2008 Oct;12(2):133-7. DOI: 10.3104/reports.2004.

21. Kokotas H, Grigoriadou M, Mikkelsen M, GiannouliaKarantana A, Petersen MB. Investigating the impact of the Down syndrome related common MTHFR 677C $>$ T polymorphism in the Danish population. Dis Markers. 2009;27(6):279-85. DOI: 10.3233/DMA-2009-0673.

22. Stuppia L, Gatta V, Gaspari A R, Antonucci I, Morizio E, Calabrese G, et al. C677T mutation in the 5,10-MTHFR gene and risk of Down syndrome in Italy. Eur J Hum Genet 2002 Jun;10(6):388-90.

23. Boduroğlu K, Alanay Y, Koldan B, Tunçbilek E. Methylenetetrahydrofolate reductase enzyme polymorphisms as maternal risk for Down syndrome among Turkish women. Am J Med Genet. 2004 May $15 ; 127 \mathrm{~A}(1): 5-10$.

24. Vranekovic J, Babic Bozovic I, Starcevic Cizmarevic N, Buretic-Tomljanovic A, Ristic S, Petrovic O, et al. Functional interference of methylenetetrahydrofolate reductase gene polymorphisms on enzyme stability as a potential risk factor for Down syndrome in Croatia. Dis Markers. 2010;28(5):293-8. DOI: 10.3233/DMA2010-0704.

25. Rai V, Yadav U, Kumar P, Yadav SK, Mishra OP. Maternal methylenetetrahydrofolate reductase C677T polymorphism and Down syndrome risk: a meta-analysis from 34 studies. PLoS One. 2014 Sep 29;9(9):e108552. DOI: 10.1371/journal.pone.0108552.

26. Yang M, Gong T, Lin X, Qi L, Guo Y, Cao Z, et al. Maternal gene polymorphisms involved in folate metabolism and the risk of having a Down syndrome offspring: a meta-analysis. Mutagenesis. 2013 Nov;28(6):661-71. DOI: 10.1093/mutage/get045.
27. Zhou-Cun A, Yang Y, Zhang SZ, Li N, Zhang W. Single nucleotide polymorphism C677T in the methylenetetrahydrofolate reductase gene might be a genetic risk factor for infertility for Chinese men with azoospermia or severe oligozoospermia. Asian J Androl. 2007 Jan;9(1):57-62.

28. Friedman G, Goldschmidt N, Friedlander Y, BenYehuda A, Selhub J, Babaey S, et al. A common mutation A1298C in human methylenetetrahydrofolate reductase gene: association with plasma total homocysteine and folate concentration. J Nutr. 1999 Sep;129(9):1656-61.

29. Van Der Put NM, Gabreëls F, Stevens EM, Smeitink JA, Trijbels FJ, Eskes TK, et al. A second common mutation in the methylenetetrahydrofolate reductase gene: an additional risk factor for neural-tube defects? J Am Col Cardiol. 1998 May;62(5):1044-51.

30. Mohanty PK, Kapoor S, Dubey AP, Pandey S, Shah R, Nayak HK, et al. Evaluation of C677T polymorphism of the methylenetetrahydrofolate reductase gene and its association with levels of serum homocysteine, folate, and vitamin B12 as maternal risk factors for Down syndrome. Indian J Hum Genet. 2012 Sep;18(3):285-9.

DOI: $10.4103 / 0971-6866.107977$. 